\title{
Formulasi Whey Fermentasi dengan Penambahan Buah Merah (Pandanus conoideus Lam) sebagai Tabir Surya
}

\author{
Fermented Whey Formulation with the Addition of Red Fruit (Pandanus conoideus Lam) as Sunscreen \\ M. Ranggawati*, I. I. Arief, \& Z. Wulandari \\ Departemen Ilmu Produksi dan Teknologi Peternakan, Fakultas Peternakan, Institut Pertanian Bogor \\ Jl. Agatis, Kampus IPB Darmaga Bogor 16680, Indonesia \\ *Corresponding author: mumusparty@gmail.com \\ (Received 31-08-2021; Revised 13-09-2021; Accepted 14-10-2021)
}

\begin{abstract}
Whey produced from cheese processing can be used as non-food products such as sunscreen by fermenting using Streptococcus thermophilus and Lactobacillus bulgaricus. Adding active ingredients such as red fruit oil which contains carotenoids can increase the effectiveness of sunscreen. This study aims to determine the formulation of fermented whey and red fruit oil usage in sunscreen. The study began with the production of fermented whey and sunscreen formulations with ratios of $0,1: 1,1: 2$, and 2:1 (fermented whey: red fruit oil). Furthermore, observe the organoleptic, antioxidant, SPF, pH, and homogeneity value. Adding fermented whey and red fruit oil showed no significant effect $(P>0.05)$ on the organoleptic test of aroma, but significantly $(\mathrm{P}<0.05)$ on color and texture. The antioxidant activity value test showed significantly different results $(\mathrm{P}<0.05)$ with $\mathrm{IC}_{50}$ values classified as moderate to high. Determination of the SPF value of sunscreen showed significantly different results $(\mathrm{P}<0.05)$, but this value was classified as low protection. Although there was no significant effect on $\mathrm{pH}$ testing $(\mathrm{P}>0.05)$, the pH of sunscreen cream indicated that it was suitable for topical application. All samples showed homogeneous results and there were no coarse particles or separation between the oil and water phases. The best sunscreen formulation is 1:1 cream with the highest SPF value of 6.86 and strong antioxidant activity with an $\mathrm{IC}_{50}$ value of $56.15 \mathrm{~g} / \mathrm{mL}$. Fermented whey and red fruit oil usage as active ingredients are more effective in increasing the protection of the cream against $\mathrm{UV}$ rays and free radicals.
\end{abstract}

Keywords: fermented whey, red fruit oil, sunscreen

\begin{abstract}
ABSTRAK
Whey yang dihasilkan dari pengolahan keju dapat dimanfaatkan menjadi produk non pangan seperti sediaan tabir surya dengan cara difermentasi menggunakan Streptococcus thermophilus dan Lactobacillus bulgaricus. Efektivitas tabir surya tersebut dapat lebih ditingkatkan dengan menambahkan bahan aktif seperti minyak buah merah yang mengandung karotenoid. Penelitian ini bertujuan untuk menentukan formulasi penggunaan whey fermentasi dan minyak buah merah pada sediaan tabir surya. Penelitian diawali dengan pembuatan whey fermentasi dan formulasi krim tabir surya dengan perbandingan (whey fermentasi: minyak buah merah) $0,1: 1,1: 2$ dan 2:1. Selanjutnya, dilakukan pengamatan terhadap nilai organoleptik, antioksidan, SPF, pH dan homogenitas. Penambahan whey fermentasi dan minyak buah merah menunjukkan hasil yang tidak berpengaruh nyata $(\mathrm{P}>0.05)$ pada pengujian organoleptik parameter aroma, namun berpengaruh nyata $(\mathrm{P}<\mathbf{0 . 0 5})$ terhadap warna dan tekstur. Pengujian nilai aktivitas antioksidan menunjukkan hasil yang berbeda nyata $(\mathrm{P}<0.05)$ dengan nilai $\mathrm{IC}_{50}$ yang tergolong sedang hingga tinggi. Penentuan nilai SPF krim tabir surya menunjukkan hasil yang berbeda nyata $(\mathrm{P}<\mathbf{0 . 0 5})$ namun nilai tersebut termasuk kategori perlindungan rendah. Pada pengujian $\mathrm{pH}$ tidak terdapat pengaruh yang nyata $(\mathrm{P}>0.05)$, namun $\mathrm{pH}$ krim tabir surya menunjukkan bahwa krim tergolong aman untuk diaplikasikan secara topikal. Semua sampel menunjukkan hasil yang homogen serta tidak terdapat partikel kasar atau pemisahan antara fase minyak dan fase air. Krim tabir surya terbaik adalah formulasi 1:1 dengan nilai SPF tertinggi sebesar 6.86 dan aktivitas antioksidan yang kuat dengan nilai $\mathrm{IC}_{50} 56.15 \mu \mathrm{g} / \mathrm{mL}$. Penggunaan whey fermentasi dan minyak buah merah sebagai bahan aktif lebih efektif dalam meningkatkan perlindungan pada krim terhadap sinar UV dan radikal bebas.
\end{abstract}

Kata kunci: whey fermentasi, minyak buah merah, tabir surya 


\section{PENDAHULUAN}

Produksi keju berbahan dasar susu menghasilkan lebih banyak produk sampingan berupa whey dibandingkan produk utamanya. Sekitar 50\% nutrisi susu terdapat pada whey, diantaranya $47 \mathrm{~g} / 1$ laktosa, $6.2 \mathrm{~g} / 1$ protein, $4.5 \mathrm{~g} / 1$ mineral, $0.5 \mathrm{~g} / 1$ lemak susu, $0.025 \mathrm{~g} / 1$ asam amino, $0.015 \mathrm{~g} / 1$ vitamin $\mathrm{C}$ dan sejumlah vitamin serta protein minor lainnya (de Wit 2001). Kandungan nutrisi yang terdapat pada whey berpotensi untuk dikembangkan menjadi berbagai produk pangan maupun non-pangan.

Pemanfaatan whey sebagai produk non pangan menjadi tren baru, hal ini disebabkan terdapatnya asam laktat dan peptida bioaktif hasil fermentasi keju (Théolier et al. 2013; Dullius et al. 2018). Whey yang merupakan limbah hasil fermentasi keju ini dapat ditingkatkan lagi komponen bioaktifnya dengan cara difermentasi kembali dengan bakteri asam laktat (BAL). Proses fermentasi whey menggunakan Streptococcus thermophilus dan Lactobacillus bulgaricus.

Fermentasi whey menghasilkan peningkatan aktivitas antioksidan, disebabkan adanya antioksidan alami seperti gluthatione, vitamin $\mathrm{C}$ dan laktoferin. Senyawa tersebut berperan dalam menghambat aktivitas enzim tirosinase sehingga dapat digunakan untuk melindungi kulit dari radiasi sinar ultraviolet (UV). Kulit yang terpapar sinar UV dari matahari dalam waktu yang lama akan menyebabkan masalah kulit seperti kemerahan, keriput, dermatitis, pigmentasi, penuaan dini dan kanker kulit (Berwick et al. 2014). Salah satu cara yang dapat dilakukan untuk mengurangi kerusakan akibat radiasi sinar matahari adalah dengan menggunakan tabir surya. Komponen dalam whey fermentasi ini dapat dibuat sediaan seperti krim tabir surya.

Tabir surya merupakan produk kosmetik yang digunakan untuk melindungi kulit dari kerusakan akibat radiasi sinar matahari, dengan cara menyebarkan sinar matahari dan menyerap atau memantulkan sinar UV yang mengenai kulit sehingga intensitas sinar matahari yang mengenai kulit akan lebih sedikit (Pratama dan Zulkarnain 2015). Efektivitas sediaan tabir surya dapat ditingkatkan dengan memperhatikan bahan aktif yang digunakan salah satu cara adalah dengan menambahkan buah merah pada sediaan.

Buah merah (Pandanus conoideus Lam) termasuk dalam suku Pandanaceae, berwarna merah dengan bentuk yang khas dan dikonsumsi sebagai bahan pangan serta bahan dasar obat (Wawo et al. 2019). Bentuk akhir yang dihasilkan dari proses ekstraksi buah merah terdiri atas bentuk pasta dan bentuk minyak yang mengandung komponen aktif berupa $\alpha$-karoten, $\beta$-karoten, $\beta$-kriptosantin, $\alpha$-tokoferol dan beberapa asam lemak tidak jenuh (Sarungallo et al. 2015).

Pengembangan produk dari whey fermentasi dapat menjadi solusi untuk mengurangi permasalahan lingkungan yang ditimbulkan akibat limbah hasil produksi keju dan menghasilkan produk yang bermanfaat serta memiliki nilai ekonomi. Whey fermentasi dan minyak buah merah dapat menjadi inovasi baru terkait diversifikasi produk berbahan alami pada kosmetik. Penelitian terkait whey fermentasi dan minyak buah merah telah banyak dilakukan, namun belum dikembangkan sebagai bahan aktif dalam tabir surya.
Komponen aktif dari whey fermentasi dan minyak buah merah berpotensi untuk meningkatkan efektivitas sediaan tabir surya. Hal ini mendukung untuk dikembangkannya penelitian krim tabir surya dengan menggunakan whey fermentasi yang didapatkan dari hasil samping pembuatan keju dan hasil ekstraksi buah merah berupa minyak. Maka perlu penentuan formulasi dan rasio yang tepat antara whey fermentasi dan minyak buah merah. Penentuan formulasi diharapkan dapat menghasilkan produk tabir surya terbaik yang stabil dan memenuhi standar keamanan.

\section{MATERI DAN METODE}

\section{Materi}

Bahan utama dari penelitian ini antara lain whey hasil samping pembuatan keju mozzarella yang diperoleh dari produksi sendiri, S. thermopilus dan L. bulgaricus yang diperoleh dari Laboratorium Terpadu Fakultas Peternakan IPB, minyak buah merah, emulgade, asam stearat, parafin cair, gliserin, trietanolamin (TEA), nipagin, dan nipasol. Bahan lain yang digunakan sebagai bahan analisis antara lain methanol p.a, asam askorbat, 2.2-diphenyl-1-picrylhydrazyl (DPPH), dan akuades.

\section{Metode \\ Pembuatan Whey Fermentasi}

Whey segar sebanyak $500 \mathrm{~mL}$ dimasukan kedalam botol Schott kemudian disterilisasi selama 3 menit pada suhu $115{ }^{\circ} \mathrm{C}$ menggunakan autoclave. Inokulasi $2.5 \% \mathrm{~S}$. thermophilus dan $2.5 \%$ L. bulgaricus dilakukan saat suhu whey mencapai $37{ }^{\circ} \mathrm{C}$. Pengadukan dilakukan hingga whey dan starter homogen, selanjutnya whey diinkubasi pada suhu $37{ }^{\circ} \mathrm{C}$ sampai mencapai $\mathrm{pH} 4.5$ (pH isoelektrik) (Rahman et al. 2014). Setelah mencapai $\mathrm{pH} 4.5$ whey disaring menggunakan syringe filter minisart $0.2 \mu \mathrm{m}$.

\section{Formulasi Krim Tabir Surya}

Bahan fase minyak dihomogenkan dalam cawan porselen di atas hotplate strirer pada suhu $\pm 75^{\circ} \mathrm{C}$ untuk menghasilkan sediaan 1. Bahan fase air dihomogenkan dalam cawan porselen di atas hotplate strirer pada suhu \pm 75 ${ }^{\circ} \mathrm{C}$ untuk menghasilkan sediaan 2. Sediaan 2 ditambahkan pada sediaan 1 dan diaduk sampai terbentuk krim basis (sediaan 3). Pengadukan dilakukan sampai suhu $\pm 40{ }^{\circ} \mathrm{C}$, kemudian ditambahkan whey fermentasi dan minyak buah merah dengan formulasi 0 (tanpa penambahan whey fermentasi dan minyak buah merah), 1:1 (whey fermentasi : minyak buah merah), 1:2 (whey fermentasi : minyak buah merah), dan 2:1 (whey fermentasi : minyak buah merah) (Ilomuanya et al. 2018). Formulasi krim tabir surya ditunjukkan pada Tabel 1.

\section{Pengujian Organoleptik}

Penilaian Organoleptik dilakukan menggunakan uji hedonik untuk mengevaluasi penerimaan panelis terhadap krim tabir surya (Carpenter et al. 2000). Parameter pengujian yang dilakukan meliputi warna, aroma, dan tekstur. Pengujian dilakukan menggunakan panelis tidak terlatih sebanyak 30 orang. Skala hedonik yang digunakan berkisar antara 1-5, dimana (1) sangat tidak suka; (2) tidak suka; (3) normal; (4) suka; (5) sangat suka. 
Tabel 1. Formulasi krim tabir surya

\begin{tabular}{lcccc}
\hline \multirow{2}{*}{ Bahan } & \multicolumn{5}{c}{ Jumlah } \\
\cline { 2 - 5 } & $0^{\mathrm{a}}$ & $1: 01$ & $1: 02$ & $2: 01$ \\
\hline $\begin{array}{l}\text { Whey fermentasi } \\
\text { minyak buah merah } \\
(\mathrm{mL})\end{array}$ & 0 & $3: 03$ & $2: 04$ & $4: 02$ \\
\hline \multicolumn{5}{c}{ Fase minyak } \\
\hline Asam stearat (g) & 2.5 & 2.5 & 2.5 & 2.5 \\
Parafin cair (ml) & 4 & 4 & 4 & 4 \\
Emulgade (g) & 8 & 8 & 8 & 8 \\
\hline \multicolumn{5}{c}{ Fase air } \\
\hline Gliserin (ml) & 3.5 & 3.5 & 3.5 & 3.5 \\
TEA (ml) & 1 & 1 & 1 & 1 \\
Nipagin (g) & 0.05 & 0.05 & 0.05 & 0.05 \\
Nipasol (g) & 0.025 & 0.025 & 0.025 & 0.025 \\
Aquades (ml) & Ad. 100 & Ad. 100 & Ad. 100 & Ad. 100 \\
\hline
\end{tabular}

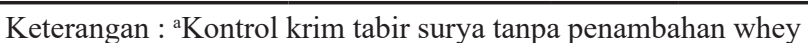
fermentasi dan minyak buah merah

\section{Uji Aktivitas Antioksidan}

Pengujian aktivitas antioksidan dilakukan dengan metode DPPH (Molyneux 2004). $10 \mathrm{mg}$ krim dilarutkan dalam $10 \mathrm{~mL}$ methanol p.a. $2 \mathrm{~mL}$ DPPH $50 \mathrm{ppm}$ ditambahkan kedalam $2 \mathrm{~mL}$ larutan krim kemudian diaduk menggunakan vorteks hingga homogen dan diinkubasi selama 30 menit. Serapan larutan standar diuji menggunakan Spektrofotometer UV-Vis single-beam (Agilent 8453 UVVisible Spectroscopy, US) dengan panjang gelombang 515 $\mathrm{nm}$. Larutan standar yang digunakan adalah asam askorbat 200 ppm.

\section{Pengujian Nilai SPF}

Penentuan nilai SPF krim tabir surya mengacu pada Mansur et al. (1986) dengan menggunakan spektrofotometer UV-Vis single-beam (Agilent 8453 UVVisible Spectroscopy, US). 1 g sampel krim dilarutkan dalam $100 \mathrm{~mL}$ etanol 96\% dan dicampur hingga homogen, kemudian disaring menggunakan kertas saring. Sebanyak 5 $\mathrm{mL}$ larutan dipindahkan kedalam labu ukur dan ditambah etanol sampai $25 \mathrm{~mL}$. Spektrum absorbansi ditentukan tiap $5 \mathrm{~nm}$ pada rentang panjang gelombang dari 290-320 nm. Etanol 96\% digunakan sebagai blanko. Absorbansi yang terukur dicatat dan dihitung nilai SPF. Perhitungan nilai SPF dilakukan dengan persamaan Mansur sebagai berikut:

$$
\operatorname{SPF}=\operatorname{CF} \times \sum_{290}^{320} \mathrm{xEE}(\lambda) \mathrm{xI}(\lambda) \mathrm{x} A b s(\lambda)
$$

Keterangan

CF : faktor koreksi bernilai 10

$\mathrm{EE}(\lambda) \quad$ : spektrum efek eritemal

I $(\lambda) \quad$ : intensitas spektrum sinar

$\operatorname{Abs}(\lambda) \quad$ : absorbansi serapan sinar

Nilai EE x I adalah konstan, ditentukan oleh Sayre et al. (1979). Nilai tersebut ditunjukkan pada Tabel 2.
Tabel 2. Nilai EE x I

\begin{tabular}{cc}
\hline Panjang gelombang $(\lambda)$ & EE x I \\
\hline 290 & 0.015 \\
295 & 0.082 \\
300 & 0.287 \\
305 & 0.328 \\
310 & 0.186 \\
315 & 0.084 \\
320 & 0.018 \\
\hline Total & 1 \\
\hline
\end{tabular}

Pengujian Nilai pH

Pengukuran $\mathrm{pH}$ dilakukan dengan menggunakan alat $\mathrm{pH}$ meter (SCHOTT® Instruments Lab 850, Germany). Kalibrasi dilakukan dengan menggunkan larutan buffer $\mathrm{pH}$ 4 dan $\mathrm{pH}$ 7. Sebanyak $0.5 \mathrm{~g}$ krim diencerkan menggunakan aquadest $10 \mathrm{~mL}$, elektroda dicelupkan kedalam larutan (Ditjen POM 1985).

\section{Pengujian Homogenitas}

Pengujian homogenitas dilakukan dengan mengamati sebaran partikel krim yang dijepit dengan dua kaca arloji. Krim harus menunjukkan susunan yang homogen dan tidak terlihat adanya butiran kasar (DEPKES RI 1995).

Penelitian ini menggunakan Rancangan Acak Lengkap (RAL) dengan satu faktor yaitu konsentrasi penambahan whey fermentasi dan minyak buah merah pada 4 taraf yaitu $0,1: 1,1: 2$ dan 2:1, dengan 3 kali ulangan. Data yang diperoleh dianalisis dengan Analysis of Variance (ANOVA) setiap analisis yang memberikan hasil beda nyata dilanjutkan dengan uji Tukey dengan selang kepercayaan 95\% (Steel dan Torrie 1995). Data hasil pengujian sensori dianalisis dengan uji non parametrik Kruskal-wallis, hasil yang berbeda nyata dilanjutkan dengan uji Mann-Whitney. Software yang digunakan adalah SPSS 16.0.

\section{HASIL DAN PEMBAHASAN}

\section{Organoleptik Krim Tabir Surya}

Pengujian organoleptik dilakukan untuk mengetahui tingkat kesukaan panelis terhadap krim tabir surya dari whey fermentasi dan minyak buah merah. Berdasarkan hasil uji Kruskal-Wallis $(\alpha=0.05)$, penambahan whey fermentasi dan minyak buah merah menunjukan hasil tidak berpengaruh nyata terhadap parameter aroma dan menunjukan hasil berpengaruh nyata terhadap warna dan tekstur. Data hasil organoleptik ditunjukkan pada Tabel 3.

Tingkat kesukaan panelis terhadap warna berkisar antara 3.07-4.00 yang berarti tidak suka hingga suka. Penambahan whey fermentasi dan minyak buah merah mempengaruhi tingkat kesukaan panelis. Uji lanjut MannWhitney menunjukkan krim kontrol, krim 2:1 dan krim 1:2 berbeda nyata sedangkan krim 1:1 tidak berbeda nyata dengan krim kontrol dan krim 2:1. Krim 1:2 memiliki tingkat kesukaan yang tertinggi yaitu 4.00 (suka). Warna krim dipengaruhi oleh kandungan karotenoid dalam minyak buah merah. Senyawa ini merupakan pigmen larut lemak 
Ranggawati et al.

Jurnal Ilmu Produksi dan Teknologi Hasil Peternakan 10 (1): 28-33

Tabel 3. Hasil uji organoleptik krim tabir surya dari whey fermentasi dan minyak buah merah

\begin{tabular}{lcccc}
\hline Parameter & \multicolumn{4}{c}{ Rata-rata uji sensori } \\
\cline { 2 - 5 } & Krim 0 & Krim 1:1 & Krim 1:2 & Krim 2:1 \\
\hline Warna & $3.07 \pm 1.05 \mathrm{a}$ & $3.37 \pm 0.98 \mathrm{ac}$ & $4.00 \pm 0.74 \mathrm{~b}$ & $3.63 \pm 0.81 \mathrm{c}$ \\
Aroma & $3.13 \pm 0.94 \mathrm{a}$ & $2.83 \pm 0.79 \mathrm{a}$ & $2.87 \pm 0.78 \mathrm{a}$ & $3.07 \pm 1.05 \mathrm{a}$ \\
Tekstur & $2.93 \pm 1.02 \mathrm{a}$ & $3.23 \pm 1.10 \mathrm{a}$ & $3.37 \pm 0.85 \mathrm{ab}$ & $3.77 \pm 1.01 \mathrm{~b}$ \\
\hline
\end{tabular}

Keterangan : Superscript yang berbeda dibelakang angka pada baris yang sama menunjukkan perbedaan nyata $(\alpha=0.05) .0=$ Kontrol,

$1: 1$ = penambahan whey fermentasi dan minyak buah merah $1: 1,1: 2=$ Penambahan whey fermentasi dan minyak buah merah $1: 2$, dan

2:1 = Penambahan whey fermentasi dan minyak buah merah $2: 1$.

yang menghasilkan warna kuning sampai merah (Rodrigues et al. 2012).

Penambahan whey fermentasi dan minyak buah merah tidak mempengaruhi aroma krim tabir surya. Tingkat kesukaan panelis berkisar antara 2.83-3.13 yang berarti tidak suka hingga normal. Hasil uji Kruskal-Wallis menunjukkan panelis lebih menyukai aroma krim dengan tanpa penambahan whey fermentasi dan minyak buah merah. Hal ini diduga karena krim dengan penambahan whey fermentasi dan minyak buah merah beraroma khas fermentasi. Laktosa yang terdapat pada whey dirombak oleh bakteri asam laktat sehingga menghasilkan senyawa asetaldehid penentu aroma (Taufik dan Maruddin 2020).

Hasil pengujian menunjukkan bahwa penambahan whey fermentasi dan minyak buah merah berpengaruh nyata terhadap tekstur krim tabir surya. Berdasarkan uji lanjut, tekstur krim 1:1 tidak berbeda nyata dengan krim kontrol namun berbeda nyata dengan krim 1:2 dan krim 2:1. tingkat kesukaan panelis berkisar antara 2.93-3.77 yang berarti tidak suka hingga normal. Krim 2:1 lebih disukai panelis. Whey fermentasi dan minyak buah merah yang ditambahkan pada sediaan tabir surya distabilkan oleh emulgator berupa asam stearat dan trietanolamin untuk mengurangi tegangan permukaan krim sehingga tekstur awal krim yang berbentuk solid (padat) berubah menjadi semi solid (setengah padat) (Chomariyah et al. 2019).

\section{Aktivitas Antioksidan Krim Tabir Surya}

Pengujian aktivitas antioksidan krim tabir surya dari whey fermentasi dan minyak buah merah dilakukan secara in vitro dengan menggunakan spektrofotometri UVVis. Aktivitas antioksidan krim tabir surya diukur dengan menentukan kemampuan krim dalam mereduksi radikal bebas DPPH sebesar 50\% (Andayani et al. 2008). Nilai yang diperoleh dinyatakan dalam nilai $\mathrm{IC}_{50}$. Hasil pengujian ditunjukkan pada Tabel 4.

Penambahan whey fermentasi dan minyak buah merah pada krim tabir surya memberikan hasil yang berpengaruh nyata. Berdasarkan uji lanjut diketahui bahwa Krim 1:1 tidak berbeda nyata dengan Krim 2:1, namun menunjukkan hasil berbeda nyata pada Krim 1:2 dan Krim Kontrol. Seperti yang ditunjukkan pada Tabel 4, Krim $1: 1(56.15 \mu \mathrm{g} / \mathrm{mL})$ memiliki efek penghambatan tertinggi terhadap radikal bebas DPPH, diikuti oleh Krim 2:1 (77.99 $\mu \mathrm{g} / \mathrm{mL})$, Krim 1:2 (121.51 $\mu \mathrm{g} / \mathrm{mL})$ dan Krim Kontrol $(182.13 \mu \mathrm{g} / \mathrm{mL})$. Perbedaan nilai aktivitas antioksidan krim tabir surya disebabkan oleh perbedaan rasio formulasi antara whey fermentasi dan minyak buah merah yang ditambahkan.
Berdasarkan hasil penelitian, semakin banyak konsentrasi minyak buah merah yang ditambahkan pada sediaan menunjukkan aktivitas antioksidan yang menurun. Hal ini dipengaruhi oleh kandungan asam lemak tak jenuh pada minyak buah merah seperti asam oleat dan asam linolenat (Ayomi 2015). Minyak yang memiliki kandungan asam lemak tak jenuh dapat mempengaruhi kecepatan oksidasi sehingga menurunkan kemampuan krim dalam menangkal radikal bebas (Setyopratiwi dan Palupi 2021). Molyneux (2004) menyatakan bahwa nilai $\mathrm{IC}_{50}$ dengan nilai $<50 \mu \mathrm{g} / \mathrm{mL}$ tergolong sangat kuat, nilai dengan rentang antara 50-100 $\mu \mathrm{g} / \mathrm{mL}$ tergolong kuat, $100-150 \mu \mathrm{g} / \mathrm{mL}$ tergolong sedang, dan $150-200 \mu \mathrm{g} / \mathrm{mL}$ tergolong lemah. Krim tabir surya dari whey fermentasi dan minyak buah merah memiliki aktivitas antioksidan yang tergolong sedang hingga kuat.

Tabel 4. Aktivitas antioksidan krim tabir surya dari whey fermentasi dan minyak buah merah

\begin{tabular}{lccc}
\hline Sampel & Abs. Blanko & $\begin{array}{c}\text { Aktivitas } \\
\text { antioksidan }(\%)\end{array}$ & $\mathrm{IC}_{50}(\mu \mathrm{g} / \mathrm{mL})$ \\
\hline Krim 0 & 1.049 & $13.12 \pm 1.78$ & $182.13 \pm 55.27 \mathrm{~b}$ \\
Krim 1:1 & 1.049 & $43.56 \pm 0.94$ & $56.15 \pm 4.89 \mathrm{a}$ \\
Krim 1:2 & 1.049 & $37.54 \pm 1.72$ & $121.51 \pm 15.83 \mathrm{ab}$ \\
Krim 2:1 & 1.049 & $40.44 \pm 0.87$ & $77.99 \pm 7.58 \mathrm{a}$ \\
\hline
\end{tabular}

Keterangan : Superscript yang berbeda dibelakang angka pada kolom yang sama menunjukkan perbedaan nyata $(\alpha=0.05) .0=$ Kontrol, 1:1 = penambahan whey fermentasi dan minyak buah merah 1:1, 1:2 = Penambahan whey fermentasi dan minyak buah merah 1:2, dan 2:1 = Penambahan whey fermentasi dan minyak buah merah 2:1.

\section{Nilai SPF Krim Tabir Surya}

Nilai Sun Protection Factor (SPF) menentukan besarnya kemampuan tabir surya dalam menangkal radiasi sinar UV. Pengukuran SPF dilakukan dengan mengukur transmitansi difusi dalam spektrum ultraviolet dari sampel krim yang digunakan berdasarkan standar eritema (Sayre et al. 1979). Spektrum yang digunakan berkisar pada panjang gelombang 290-320 nm untuk menentukan kemampuan krim tabir surya dalam melindungi kulit dari sinar UV B. Dampak negatif dari sinar UV dapat dikurangi dengan menggunakan krim yang mengandung SPF, semakin tinggi nilai SPF krim maka semakin efektif pula kemampuan krim tersebut dalam melindungi kulit dari pengaruh buruk sinar UV. Hasil analisis nilai SPF ditunjukkan pada Tabel 5.

Formulasi krim tabir surya dari whey fermentasi dan minyak buah merah dengan rasio yang berbeda 
menunjukkan hasil yang berbeda nyata terhadap nilai SPF. Bahan aktif berupa whey fermentasi dan minyak buah merah yang ditambahkan pada sediaan menghasilkan krim dengan nilai SPF yang lebih tinggi dibandingkan dengan krim tanpa penambahan bahan aktif. Rahman et al. (2014) menyatakan bahwa Whey yang difermentasi dengan $S$. thermophilus dan L. bulgaricus menghasilkan efek penghambatan enzim tirosinase sebesar $69.19 \pm 1.16 \%$ lebih tinggi dibandingkan dengan whey yang difermentasi dengan L. plantarum dan kefir. Enzim tirosinase berperan dalam mengubah tirosin menjadi 3,4-dihidroksifnilalanin (DOPA) selanjutnya menjadi dopakuinon dan dikonversi menjadi melanin yang berperan dalam melindungi kulit dari sinar UV (Charissa et al. 2016). Kandungan karotenoid yang terdapat pada minyak buah merah dapat melindungi kulit dari sinar UV dan lebih aman dibandingkan bahan kimia sintetis berdasarkan efek jangka panjang (Donglingkar dan Deore 2018). B-karoten yang terdapat pada tabir surya berfungsi untuk meregenerasi kulit dan memberikan pigmen bercaya pada kulit (Zia-UlHaq et al. 2021).

Krim 1:1 memiliki faktor proteksi yang lebih tinggi dibandingkan dengan Krim 1:2 dan Krim 2:1. Perbandingan yang setara antara whey fermentasi dan minyak buah merah lebih efektif dalam meningkatkan nilai perlindungan pada krim. Hal ini menunjukkan bahwa Krim 1:1 lebih efektif dalam melindungi kulit dari dampak negatif sinar UV. Perlindungan tabir surya terhadap sinar UV dibedakan berdasarkan empat level yaitu level rendah (SPF $\geq 6-<$ $15)$, level sedang (SPF $\geq 15-<30)$, level tinggi (SPF $\geq 30$ $-<50$ ), dan level sangat tinggi (SPF $\geq 50-50+$ ) (BPOM 2017). Berdasarkan hasil penentuan nilai SPF, krim tabir surya dengan penambahan whey fermentasi dan minyak buah merah termasuk dalam kategori perlindungan rendah.

Tabel 5. Nilai SPF, pH dan homogenitas krim tabir surya dari whey fermentasi dan minyak buah merah

\begin{tabular}{lccc}
\hline \multicolumn{1}{c}{ Sampel } & $\mathrm{SPF}$ & $\mathrm{pH}$ & Homogenitas \\
\hline Krim 0 & $0.55 \pm 0.04 \mathrm{a}$ & $6.58 \pm 0.13 \mathrm{a}$ & Homogen \\
Krim 1:1 & $6.86 \pm 0.17 \mathrm{~d}$ & $6.59 \pm 0.37 \mathrm{a}$ & Homogen \\
Krim 1:2 & $3.35 \pm 0.39 \mathrm{~b}$ & $6.22 \pm 0.14 \mathrm{a}$ & Homogen \\
Krim 2:1 & $5.06 \pm 0.33 \mathrm{c}$ & $6.17 \pm 0.06 \mathrm{a}$ & Homogen \\
\hline
\end{tabular}

Keterangan : Superscript yang berbeda dibelakang angka pada kolom yang sama menunjukkan perbedaan nyata $(\alpha=0.05) .0=$ Kontrol, 1:1 = penambahan whey fermentasi dan minyak buah merah 1:1, 1:2 = Penambahan whey fermentasi dan minyak buah merah 1:2, dan 2:1 = Penambahan whey fermentasi dan minyak buah merah 2:1.

\section{Nilai pH Krim Tabir Surya}

Pengujian nilai $\mathrm{pH}$ dilakukan untuk mengetahui tingkat penerimaan produk krim tabir surya pada kulit. Safitri et al. (2014) menyatakan bahwa pH sebagai indikator keamanan krim dinyatakan aman untuk diaplikasikan pada kulit apabila memiliki pH yang mendekati $\mathrm{pH}$ normal kulit. pH normal kulit berada pada interval 4.5-6.5 (Faradiba et al. 2013).

Hasil pengujian (Tabel 5) menunjukkan bahwa penambahan whey fermentasi dan minyak buah merah tidak memberikan pengaruh yang nyata terhadap $\mathrm{pH}$ krim tabir surya. Berdasarkan SNI 16-4399-1996, pH krim yang aman untuk kulit berkisar antara 4.5-8. Krim dengan $\mathrm{pH}$ yang terlalu asam dapat menyebabkan masalah pada kulit seperti iritasi, dikarenakan mantel asam lapisan stratum korneum rusak dan tidak dapat mempertahankan pembentukan lemak epidermis sehingga kulit mengalami iritasi (Levin dan Maibach 2008). Masalah kulit yang disebabkan oleh krim dengan $\mathrm{pH}$ yang terlalu basa adalah kulit yang kering seperti bersisik (Sharon et al. 2013). pH krim tabir surya berkisar pada 6.17-6.59, berdasarkan $\mathrm{pH}$ normal kulit dan standar SNI 16-4399-1996 krim tabir surya yang dihasilkan tergolong aman untuk diaplikasikan secara topikal.

\section{Homogenitas}

Pengujian homogenitas dilakukan untuk mengamati partikel kasar yang terdapat pada krim yang menandakan bahwa krim tidak tercampur rata. Berdasarkan hasil pengujian (Tabel 5), semua sampel menunjukkan hasil yang homogen serta tidak terdapat partikel kasar atau pemisahan antara fase minyak dan fase air.

Homogenitas krim tabir surya dari whey fermentasi dan minyak buah merah disebabkan oleh adanya emulsifier seperti asam stearat dan trietanolamin. Interaksi antar keduanya menghasilkan sediaan krim dengan konsistensi yang stabil, halus dan rigid (Rowe et al. 2009). Chomariyah et al. (2019) melaporkan bahwa kombinasi asam stearat $14.02 \%$ dan trietanolamin $0.41 \%$ merupakan formulasi optimum sebagai emulgator anionic yang meningkatkan mutu fisik krim yang dihasilkan.

\section{KESIMPULAN}

Formulasi whey fermentasi dan minyak buah merah terbaik yang digunakan dalam sediaan krim tabir surya yaitu Krim 1:1, dengan nilai SPF sebesar 6.86 dan nilai $\mathrm{IC}_{50}$ sebesar $56.15 \mu \mathrm{g} / \mathrm{mL}$, serta tingkat kesukaan panelis yang berkisar normal. Krim memiliki nilai $\mathrm{pH}$ yang tergolong aman untuk diaplikasikan secara topikal yaitu 6.59 dan secara homogenitas tidak terdapat partikel kasar pada krim.

\section{DAFTAR PUSTAKA}

Andayani, R., Y, Lisawati., \& Maimunah. 2008. Penentuan aktivitas antioksidan, kadar fenolat total dan likopen pada tomat (Solanum lycopersium L). JSTF. 13(1): $1-9$.

Ayomi, A. F. M. 2015. Buah merah (Pandanus conoideus) terhadap penyerapan zat besi (Fe) dalam duodenum. J Agromed Unila. 2(2): 90-93.

Berwick, M., C. Pestak, \& N. Thomas. 2014. Solar ultraviolet exposure and mortality from skin tumors. ADV Med Biol. 810: 342-58.

Badan Pengawas Obat dan Makanan. 2017. Raperka BPOM Nomor 19 Tahun 2015 Persyaratan Teknis Kosmetika. Badan Pengawas Obat dan Makanan, Jakarta.

Badan Standarisasi Nasional. 1996. SNI 16-4399 Sediaan Tabir Surya. Badan Standarisasi Nasional, Jakarta. 
Carpenter, R. P., D. H. Lyon, \& T. A. Hasdell. 2000. Guildelines for sensory analysis in food product development and quality control. Ed ke-2. Marylands Aspen Publisher, Maryland.

Charissa, M., D. Joshita, \& E. Berna. 2016. Uji aktivitas antioksidan dan penghambatan tirosinase serta uji manfaat gel ekstrak kulit batang taya (Nauclea subdita) terhadap kulit. J. Kefarmasian Indones. 6(2): 98-107.

Chomariyah, N., L. D. Farida, \& W. Sumi. 2019. Optimasi sediaan pelembab ekstrak kering kulit buah manggis (Garcinia mangostana L.) dengan kombinasi asam stearat dan trietanolamin sebagai emulgator. J. Pharmacy Science and Practice. 6(1): 16-23.

De Wit, J. N. 2001. Lecture's Handbook on Whey and Whey Product. European Whey Products Association, Belgium.

DEPKES RI. 1995. Farmakope Indonesia. Ed ke-4. Departemen Kesehatan Republik Indonesia, Jakarta.

Ditjen POM. 1985. Formularium Kosmetika Indonesia. Departemen Kesehatan RI, Jakarta.

Donglikar, M. M., \& S. L. Deore. 2018. Sunscreens: a review. Pharmacognosy J. 8(3): 171-179.

Dullius, A., M. I. Goettertb, \& C. V. Souza. 2018. Whey protein hydrolysates as a source of bioactive peptides for functional foods-Biotechnological facilitation of industrial scale-up. J. Funct Foods. 42: 58-74.

Faradiba., A. Faisal., \& M. Ruhama. 2013. Formulasi krim wajah dari sari buah jeruk lemon (Vitis vinifera L.) dengan variasi konsentrasi emulgator. MFF. 17(1): 17-20.

Ilomuanya, M. O., T. Ajayi, I. Cardoso-Daodu, T. Akhimien, O. Adeyinka, \& C. Aghaizu. 2018. Formulation and evaluation of polyherbal antioxidant face cream containing ethanol extracts of Psidium guajava and Ocimum gratissimum. Nig J. Pharm. 14(1): 61-68.

Levin, J., \& H. Maibach. 2008. Human skin buffering capacity: an overview. J. Skin Research and tech. 14: 121-126

Mansur, J. S., M. N. R. Breder, M. C. A. Mansur, \& R. D. Azulay. 1986. Determination of sun protection factor by spectrophotometry. Bras Dermatol. 61: 121-124.

Molyneux, P. 2004. The use of stable free radical diphenylpicrilhydrazyl (DPPH) for estimating antioxidant activity. JST. 26(2): 211-219.

Pratama, W. A., \& A. K. Zulkarnain. 2015. Uji SPF in vitro dan sifat fisik beberapa produk tabir surya yang beredar di pasaran. Majalah Farmaseutik. 11(1): 275283.

Rahman, A., E. Taufik, S. Purwantiningasih, \& B. P. Purwanto. 2014. Kajian potensi whey yogurt sebagai bahan alami pencegah jerawat. JIPTHP. 2(1): 238-242.
Rodrigues, E., L. R. B. Mariutti, \& A. Z. Mercadante. 2012. Scavenging capacity of marine carotenoids against reactive oxygen and nitrogen species in a membrane-mimicking system. Mar drugs. 10(8): 17841798.

Rowe, R. C., P. J. Sheskey, \& M. E. Quinn. 2009. Handbook of phamaceutical excipient 6th. Pharmaceutical Press and American Phamacists Assosciation, Washington D.C.

Safitri, N. A., O. K. Puspita., \& V. Yunita. 2014. Optimasi formula sediaan krim ekstrak stroberi (Fragaria $x$ ananassa) sebagai krim anti penuaan. Majalah Kesehatan FKUB. 1(4): 235-246.

Sarungallo, Z. L., P. Hariyadi, N. Andarwulan, \& E. H. Purnomo. 2015. Analysis of $\alpha$-cryptoxanthin, $\beta$ cryptoxanthin, $\alpha$-carotene, and $\beta$-carotene of Pandanus conoideus oil by high-performance liquid chromatography (HPLC). Procedia Food Sci. 3: 231243.

Sayre, R. M., P. P. Agin, G. J. Levee, \& E. Marlowe. 1979. Comparison of in vivo and in vitro testing of sun screening formulas. Photochem Photobiol Oxford. 29(3): 559-66.

Setyopratiwi, A., Palupi, N. F. 2021. Formulasi krim antioksidan berbahan virgin coconut oil (VCO) dan red palm oil (RPO) dengan variasi konsentrasi trietanolamin. BJP. 1(1): 26-39.

Sharon, N., S. Anam., \& Yuliet. 2013. Formulasi krim antioksidan ekstrak etanol bawang hutan (Eleutherine parmifolia L. Merr). JNS. 2(3) : 111-122.

Steel, R. G. D., \& J. H. Torrie. 1995. Prinsip dan Prosedur Stastistik: Suatu Pendekatan Biomentrik Terjemahan: B. Sumantri. PT Gramedia Pustaka Utama, Jakarta.

Taufik, M., F. Maruddin. 2020. Karakteristik sensoris produk minuman whey fermentasi dengan penggunaan presentase sukrosa. JTIP. 30(1): 36-42.

Theolier, J., R. Hammami, P. Labelle, I. Fliss, \& J. Jean. 2013. Isolation and identification of antimicrobial peptides derived by peptic cleavage of whey protein isolate. J. Funct Foods. 5: 706-714.

Wawo, A. H., P. Lestari, \& N. Setyowati. 2019. Buah merah (Pandanus conoideus Lam) bioresources pegunungan tengah Papua: Keanekaragaman dan upaya konservasinya. J. Biol Indones. 15(1): 107-121.

Zia-Ul-Haq, M., M. Bin-Jumah, S. A. Suaad, M. Marius, B. Lavinia, \& B. Nicu. 2021. Carotenoids: Structure and function in the human body. Springer, Switzerland. 